\title{
Trends and Prospects of Higher Education Development in Russia by the Example of Training of Specialists in the Field of Economics
}

\author{
Elena Ivanovna Fakhrislamova*, Tatiana Vitalievna Dolgikh, Inna Vladimirovna \\ Pevneva and Ianina Vasilievna Formulevich \\ Kemerovo Institute (Affiliated Branch) of the Federal State Budgetary Educational Institution \\ of Higher Professional Education (FSBEl of HPE), Plekhanov Russian University of Economics, Russia; \\ monblan.pro@yandex.ru
}

\begin{abstract}
In this article, the authors study the modern trends of higher education development in Russia within the framework of the professional training of specialists in the field of economics. The purpose of this research is involvement of concerned persons into the academic discussion. The authors have examined the current approach to the educational process of the professional training of specialists and studied the positive experience of implementation of the multilevel model of the specialist training in the field of economics. A study and implementation of this multilevel model of specialist training in the field of economics was carried out at the premises of one of the largest higher education institutions in Russia, namely, the Kemerovo Institute (affiliated branch) of the Plekhanov Russian University of Economics.
\end{abstract}

Keywords: Academic Environment, Accounting, Analysis, Auditing, Competency-Based Approach, Educational Process, Higher Education, Multilevel Educational Model, Training Process

\section{Introduction}

This study is relevant because the requirements to an economist in the field of accounting, analysis and auditing have been raised at the modern stage of development of the society and economics in general. It is reflected in the necessity of the implementation of unique professional solutions in the conditions of non-standard situations. It is reasonable to suppose that such specialists should have a certain qualification, which is currently achieved by implementation of the multilevel system of specialist training in this field.

\subsection{Objective, Methods and Stages of Research}

The objective of this study is to consider the issues of compliance of the current education model in Russia with the changing demands of the population, the long-terms objectives of the society and economy in general.

In this research, we used the following methods: induction, deduction, synthesis, analysis, and grouping.

\section{Research Stages}

- Consideration of the current regulatory framework for the studied issues;

- Analysis of the multilevel system of higher professional education in Russia;

- Presentation of a set of questions within the studied topic for further discussion about modern prospects in the development of higher professional education in Russia.

\footnotetext{
${ }^{*}$ Author for correspondence
} 


\section{Body of the Work}

In recent decade, the Russian society has taken a range of important measures for modernization of the higher education content, improvement of its quality and integration of the Russian professional education into the international educational space.

One of the main patterns of "Education Development" determined by the state program of the Russian Federation for 2013 - 2020 is the increase in the number of educational institutions of secondary vocational and higher education and complete meeting of the Russian economics' demand for highly-qualified human resources for the priority patterns of technological development modernization.

On the basis of the program "Education Development in 2013-2020"', one of the development trends of the labor potential of the enterprises and organizations is the formation of their own personnel training programs within the frameworks of their own training centers. Pursuant to the existing practice, employers prefer to provide additional training or re-training of their employees within their own educational structural units. Such a trend is quite widely spread within the scope of the internal training of employees in companies (organizations) all over the world. One of the key objectives of a corporate training program is the development of closer interrelation between the professional educational subject and the labor market demand.

Within the framework of the Programimplementation, a chain of professional education organizations and institutions will establish a structure, which, in its turn, will comply with the economy requirements. This chain will include leading research universities (40-60 higher education institutions), whose aim is the promotion, formation and development of the innovation-driven economy, and along with them, back-up higher education institutions of the regional economic systems will be formed, whose aim will be to provide specialized professional training. Higher education institutions with an extended system of bachelors' training will complete the chain of organizations and institutions. As for the top-qualification personnel training (postgraduates), this type of education will be mostly attributed to research universities.

It is worth noting that in the majority of higher education institutions, along with bachelors' and masters' training programs, applied bachelor's programs will be developed and further implemented. Within the framework of the Program implementation by 2020, all students will have to study according to their individual plans based on a prevailing portion of self-tuition within the scope of professional education obtaining with account of modern information technology application.

Along with that, in terms of the regional aspect, two types of organizational chains will be developed, whose aim is the implementation of secondary vocational education programs and obtaining of applied professional qualifications; in addition, flexible modular programs of advanced training and professional retraining will be formed.

Within the framework of this aspect, it should be noted that, on the one hand, geographically accessible multi-discipline colleges with flexible variable educational programs will be established. On the other hand, key (leading) branch enterprises (companies) together with the state will be developing chains of organizations (institutions), whose aim will be the implementation of applied professional educational programs, and secondary professional education institutions within the framework of certain branches. In this case, the process of enlargement of higher and secondary professional education institutions will result in their total number reduction.

One of the components of the educational space are non-state educational institutions, which will be developed as part of a fair competition with the state sector by providing access of accredited educational programs of non-state educational institutions to budget funding.

According to the developers of the Program, such a pattern will result in an improvement of the educational services' quality in this sector and in education in general. Finally, this pattern is to reach a share of $30 \%$ of the entire professional education sector.

The improvement of the secondary professional education quality and, as a result, of the workplaces quality, as well as introduction of applied bachelor's programs, targets ensuring a relative growth of the share of students involved in the corresponding educational programs. Short-term programs of advanced training of life skills throughout the life are to be developed at a fast rate.

One of the priority aspects of the continuous education system must be the system of qualification certification, including certification of a qualification obtained by selftuition. 
A postgraduate system, which will be concentrated at research universities, is aimed at strengthening the links between science and professional education, which is to ensure a transition of the scientific personnel training process to a higher, qualitative level, including in the interests of the higher school.

All students will be provided with the opportunity to participate in research and development according to their specialization during the senior years of their bachelor's programs and during the study at specialists' and masters' programs. Best graduates of schools and bachelor's programs desiring to obtain education of the most advanced level will have such an opportunity in Russia, since in the result of the Program implementation, at least five Russian higher education institutions will join the top 100 world universities according to the main international rating systems, and at least thirty Russian higher education institutions will implement joint postgraduate and master's programs with leading international universities.

Due to the qualitative changes in the educational activity, real environment and opportunities for language proficiency development will be formed at higher education institutions. This, in its turn, will allow to bring the development of international academic exchanges to a whole new level, which is significant for our country, which is a party to the Bologna process ${ }^{1}$.

Thus, the above-mentioned patterns reflect the prospects of higher professional education development in Russia.

At present time, modernization of the structure and content of professional education is being performed in accordance with approved federal national educational standards complying with the requirements of the national economy's development and with a transition to multi-level higher education-bachelor's and master's programs.

Higher education institutions implementing various educational programs, including the Kemerovo Institute (affiliated branch) of the Plekhanov Russian University of Economics, implement the following multilevel model of graduate's education: pre-university education, secondary professional education, higher education: bachelor's, specialist's, master's degrees; top-qualification personnel training; extended education: advanced training, professional re-training.

All higher education institutions annually update their basic educational programs with account of the science, culture, economy, engineering, technology and social sphere development.

Upon educational programs development, higher education institutions form a socio-cultural environment providing the conditions required for comprehensive personal development and contributing to the development of the socio-educational component of the training process, including the development of student self-governance, students' participation in social organizations, sports and creative groups and scientific student communities.

Within the framework of the competency-based approach implementation, the application of interactive and active forms of classes (business and role games, computer simulations, case studies, psychological and other trainings) is practiced at the beginning of the educational process jointly with extracurricular work for the purpose of formation and development of students' professional skills.

For this purpose, higher education institutions (within the framework of training courses) arrange meetings with representatives of Russian and foreign companies, state and public organizations and master-classes of experts and specialists.

Students of higher education institutions have now a real opportunity to participate in the formation of their academic program, including the development of individual education programs.

Further on, by the example of our higher education institution, we will consider the current process of graduate training in the field of economics in a particular discipline - Accounting, Analysis and Auditing.

As is known, modern economic situation radically changes the attitude to the profession of an accountant. Participation in the organization's affairs makes an accountant a managing professional, whose primary activity aim is diagnostics and development of measures contributing to the protection of the organization's wellbeing throughout the complete period of its existence. There is a permanent link between financial management and management accounting, which lies in the fact that business information must be relevant to the business aims. Such a role of an accountant and accounting is obvious, since it is supported by the work experience of most countries, and complies with all professional standards adopted in the international practice.

Improvement of the accounting and reporting process of an economic entity is impossible without modernizing 
the accountant's profession. This, on the one hand, is associated with significant changes in accounting methods and technologies, extended application of economic and mathematical modeling, computers, advanced software products, searching for information systems, information databases. On the other hand, it is associated with external conditions: the economic life has become much faster and more diverse, the accounting standards and legal frameworks, which accountants use in their work, have also modified significantly, the integration processes have become more intensive, the taxation system is being modified, etc. The accounting basis itself targets focusing an accountant on evaluating various options and selecting the one, which best conforms to the production tasks and condition.

At present time, significant changes in the economic sphere take place in Russia; our country is increasingly integrated into the global economy. This, undoubtedly, determines the necessity of conducting professional activity with account of international regulations and principles in the conditions of the single national policy.

The change in the public relations system, as well as the civil-legal environment, causes the necessity of proper transformation of the national accounting and reporting system, the reforming process of which to a large extent determines the development of the economy of the whole country.

Since January 1, 2013, the accounting regulatory system in our country has changed dramatically. Thus, according to Article 21 of the Federal law "On Accounting" No. 402-FZ, the accounting regulation documents will include:

- Federal standards;

- Branch standards;

- Accounting recommendations;

- Standards of an economic entity ${ }^{2}$.

These changes are connected with the transition of the national accounting and reporting system to international standards. Due to the fact that currently these documents are in the process of development, accounting and reporting in Russia should comply with the requirements of the Russian Accounting Standards (RAS):

AR (Accounting Regulation) 1/2008 "Accounting Policy of an Organization". This regulation determines the rules of formation (selection or development) and disclosure of the accounting policies of organizations acting as legal entities under the law of the Russian Federation (except credit and state (municipal) institutions $)^{3}$.
AR 2/2008 "Construction Contracts Accounting", which determines the peculiarities of the procedure of generation in accounting records of the information about profits, expenses and financial results of organizations (except credit organizations and state (municipal) institutions), acting as legal entities under the law of the Russian Federation, and as contractors or subcontractors according to construction contracts, the execution period of which amounts to more than one reporting year (longterm contracts), or the commencement and completion terms of which fall on different reporting years, and the disclosure of such information in accounting reports ${ }^{4}$.

AR 3/2006 "Accounting of Assets and Liabilities in Foreign Currency". This regulation determines the peculiarities of generation in accounting records and reports of the information about assets and liabilities, the cost of which is expressed in foreign currency, including those payable in Russian rubles, by organizations acting as legal entities under the law of the Russian Federation (except credit organizations and state (municipal) institutions $)^{5}$.

AR 4/99 "Accounting Reports of an Organization" determines the scope, content and methodological principles of generation of accounting reports in organizations acting as legal entities under the law of the Russian Federation, apart from credit organizations and state (municipal) institutions ${ }^{6}$.

AR 5/01 "Inventory Accounting". This regulation determines the rules of generation in accounting records of the information about the organization's inventories?

AR 6/01 "Fixed Assets Accounting" contains the rules of generation in the accounting records of the information about fixed assets of an organization . $^{2}$

AR 7/98 "Post-Reporting Events" determines the procedure for post-reporting events disclosure in the accounting reports of commercial organizations (except credit institutions), acting as legal entities under the law of the Russian Federation?.

AR 8/2010 "Estimated Liabilities, Provisional Liabilities and Assets" determines the procedure for disclosure of estimated liabilities, provisional liabilities and assets in the accounting records and reports of organizations (except credit organizations and state (municipal) institutions), acting as legal entities under the law of the Russian Federation ${ }^{10}$.

AR 9/99 "Incomes of an Organization". This regulation determines the rules of generation in the accounting records of the information about the incomes 
of commercial organizations (except credit and insurance organizations), acting as legal entities under the law of the Russian Federation ${ }^{11}$.

AR 10/99 "Expenses of an Organization" determines the rules of generation in the accounting records of the information about the expenses of commercial organizations (except credit and insurance organizations), acting as legal entities under the law of the Russian Federation $^{12}$.

AR 11/2008 "Related Parties Disclosure". This regulation determines the procedure of disclosure of the information about the related parties in the accounting of commercial organizations, except credit organizations (hereinafter referred to as "the organization preparing accounting reports") ${ }^{13}$.

AR 12/2010 "Segmented Information" determines rules of segmented information generation and presentation in the accounting reports of commercial organizations (except credit organizations), acting as legal entities under the law of the Russian Federation ${ }^{14}$.

AR 13/2000 "Government Assistance Accounting". This regulation determines the rules of generation in the accounting records of the information about the receipt and disposal of government assistance provided to commercial organizations (except credit organizations) acting as legal entities under the law of the Russian Federation, and admitted as an increase in the economic benefit of a particular organization in the result of assets receipt (monetary funds, other property) ${ }^{15}$.

AR 14/2007 "Intangible Assets Accounting" determines the rules of generation in the accounting records and disclosure in the accounting reports of the information about intangible assets of organizations acting as legal entities under the law of the Russian Federation (except credit organizations and state (municipal) institutions) ${ }^{16}$.

AR 15/2008 "Accounting of Expenses for Loans and Credits". This regulation determines the peculiarities of generation in the accounting records and reports of the information about expenses related to the fulfillment of obligations under received loans (including fundraising by means of issuing bills, issuing and selling bonds) and credits (including supplier's and commercial credits) of organizations acting as legal entities under the law of the Russian Federation (except credit organizations and state (municipal) institutions) ${ }^{17}$.

AR 16/02 "Terminated Activity Disclosure" determines the procedure for the disclosure of information about a terminated activity in the accounting reports of commercial organizations (except credit organizations) acting as legal entities under the law of the Russian Federation ${ }^{18}$.

AR 17/02 "Accounting of Expenses for R\&D and Technological Works". This regulation determines the rules of generation in the accounting records and reports of commercial organizations acting as legal entities under the law of the Russian Federation (except credit organizations) of the information about the expenses related to research and development, development and engineering, and technological works ${ }^{19}$.

AR 18/02 'Profit Tax Accounting of Organizations" determines the rules of generation in the accounting records of the information about tax profit calculations of organizations admitted as profit tax payers according to the procedure provided by the law of the Russian Federation (except credit organization and state (municipal) institutions), and disclosure of such information in the accounting reports, as well as determines the interrelation of the profit (loss) value calculated according to the procedure determined by regulatory acts of the Russian Federation on accounting, and the profit tax base for the reporting period calculated according to the procedure determined by the law of the Russian Federation on taxes and levies ${ }^{20}$.

AR 19/02 "Investments Accounting" determines the rules of generation in the accounting records and reports of the information about financial investments of an organization. In this case, an organization is recognized as a legal entity under the law of the Russian Federation (except credit organizations and state (municipal) institutions) $)^{21}$.

AR 20/03 "Joint Venture Information Disclosure". This regulation determines the rules and procedure for the disclosure of information in the accounting reports about participation in joint activities of commercial organizations (except credit organizations) acting as legal entities under the law of the Russian Federation ${ }^{22}$.

AR 21/2008 "Change of Estimated Values" determines the rules of recognition and disclosure of the information about the estimated values' changes in the accounting reports of organizations acting as legal entities under the law of the Russian Federation (except credit organizations and state (municipal) institutions) ${ }^{23}$.

AR 22/2010 "Correction of Mistakes in the Accounting Records and Reports". This regulation determines the rules of mistake correction and procedure of disclosure of the information about mistakes in the accounting records 
and reports of organizations acting as legal entities under the law of the Russian Federation (except credit organizations and state (municipal) institutions) ${ }^{24}$.

AR 23/2011 "Cash Flow Statement" determines the rules of reporting about cash flow by commercial organizations acting as legal entities under the law of the Russian Federation (except credit organizations) ${ }^{25}$.

AR 24/2011 "Accounting of Expenses for Natural Resources Development". This regulation determines the procedure for generation of the information about the expenses for the natural resources development in the accounting records and disclosure of such information in the accounting reports of organizations acting as legal entities under the law of the Russian Federation (except credit organizations and state (municipal) institutions ${ }^{26}$.

The adoption of IAS predetermined more active participation of self-regulatory organizations in this process.

Modern conditions are distinctive in that the education system, in which the accounting education holds an important position, also experiences radical changes, and the accountant profession is also exposed to such changes.

At present time, this task is being solved at the government level. Thus, the plan of the Ministry of Finance of Russia for 2012-2015 "On Accounting Records and Reports Development in Russia on the Basis of International Standards" (as amended by Order of the Ministry of Finance of Russia dated 30.11.2012 No. 455) contains an entire section covering the profession development.

The plan includes certain measures for expansion of the training and advanced training system for specialists in the field of accounting (financial) reports preparation, auditing, application, control and supervision in accordance with IAS; measures for development of the system of professional certification of accountants on the basis of the professional standards of the International Federation of Accountants (IFAC); introduction of the system of regular advanced training of the accounting specialists on the basis of the IFAC standards, etc.

Self-regulatory organizations of professional accountants and auditors also take an active part in this process. Thus, in particular, the Non-Profit Partnership "Accountants Association Sodruzhestvo" within the framework of the development of a specialist training system with the purpose of certification and award of qualification certificates of various levels carries out the following steps: develops regulatory documentation describing the relations between the Non-Profit Partnership "Accountants Association Sodruzhestvo" and training and methodological centers, higher education institutions, etc.; develops training programs with further issuance of qualification certificates of various levels; develops proposals to ensure the compliance of the higher education institutions' educational programs and programs of professional accountants, financial managers and management accounting specialists' training with the international educational standards; arranges the methodological work with the teaching personnel of training and retraining methodological centers; develops study guides for the programs of professional accountants, financial managers and management accounting specialists' training and certification; participates in the establishment of the workgroup of teachers representing higher education and practice-oriented specialists for the purpose of the specialist training programs update; promotes a minimum knowledge level for the professional recognition among higher education institutions, students and other concerned parties; arranges distance certification and advanced training; attracts retired professionals and teachers to train specialist for the certification and qualification upgrade; provides training materials via mass media, including Internet, etc.

As a result, all changes occurring in our country in the field of the accounting regulations, reporting and record-keeping significantly change the requirements to specialists in this area as well. Adoption of the international accounting standards contributes to a more comprehensive application of the professional skills and knowledge, professional assumptions upon settlement of various economic tasks, and, accordingly changes the approach to such specialists training in general. In such conditions, there is an increasing demand for professional accountants, i.e. specialists who have obtained not only higher professional education, but also have been trained with account of the recent changes in the area of taxation, accounting and law.

A professional accountant must be a qualified expert capable of meeting the demands of the new economy and having proper communication skills. In addition to the above-stated, a professional accountant must also be a financial analyst, business consultant, manager, capable of handling public relations and taking part in negotiations. However, the fundamental qualities of the people of such profession are objectiveness, commitment and honesty.

The term "professional accountant" also implies ethical norms and accounting values. 
Accountants play an increasingly important role in the operational management of an organization. Quite recently, accountant's duties were limited to representation of data, which were further applied by other persons, but today an accountant is a decision-taking team member. This has resulted in the increased significance of the organizational and managerial aspects of the professional accountant's work.

Accountant's work is dynamic; an accountant is acting in constantly changing circumstances. The most essential knowledge for an accountant is that acquired throughout the whole professional career. An accountant must take care of his/her continuous professional education in order to maintain skills and knowledge at an adequate level, meeting modern requirements of business practice, science and law.

The accountant profession improvement is impossible without the development of accounting records keeping and reporting. On the one hand, this task implies training of properly qualified accountants and auditors, who are to be proficient in modern accounting methods, understand certain rules and principles of information generation in accounting records and reports, and audits capable of accounting reports preparation.

On the other hand, a proper system of accounting records keeping and reporting assumes the existence of a sufficient number of users who need the information generated in the accounting records and reports, who need to apply it when taking economic decisions and have proper skills for that, including when taking decisions in the capital investment area and analysis of associated risks. The existence of interested users is a prerequisite of the accounting records keeping and reporting system development. Special attention in the considered area upon determination of the advanced training scope and personnel training process must be paid to the following aspects:

- IAS are based on the principles of implementation of the concept of information significance and money value usefulness, the priority of the economic component over the legal form, capital preservation, etc.;

- Formation and development of application skills, individual methods of information processing, such as: mathematical statistics, possible estimates, discounting, etc.;

- Development and formation of a new approach within the frames of application of standards and other regulatory acts in the field of accounting records keeping and reporting;
- Application and formation of the skills of active application of the information generated in the accounting record keeping in the process of economic entity management and effective corporate management;

- Refocusing the training programs of specialized secondary and higher education institutions, as well as of the programs of professional accountant and auditors training on the basis of enhanced study of IAS, and application of the skills in practice;

- Comprehensive application, understanding and observance of the professional code of ethics.

The main patterns of improvement of the personnel training and qualification upgrade in the field of accounting record keeping must be the following ones:

- Monitoring of the quality of education programs of specialized secondary and higher education institutions, as well of professional accountants and auditors training programs;

- Acquisition of skills of professional assumption upon qualification, evaluation of facts' importance (significance) and cost measurement of the economic life for the accounting, reporting and auditing purposes;

- Teaching in the application of financial indicators generated according to IAS procedures in the system of national accounts;

- Development of training programs for managers and other executive staff of economic entities on the fundamentals of accounting and economic analysis of accounting reports and consolidates financial statements;

- Development of Russian standards of education and certification of professional accountants and auditors on the basis of the IFAC standards;

- Development of training programs for professional accountants and auditors in compliance with the international programs, but with account of the traditions of the accounting education and law of the Russian Federation;

- For different categories of trainees, development and update of new study guides on accounting records keeping and reporting.

To achieve the set objectives, our higher education institution within the framework of the traditional forms and methods of organizing and holding classes in the process of education applies the method of visualization of presented training and illustrating materials, reflecting the development stages, in particular, of the statistics of Russia and the Kemerovo region; economic analysis methodology; practice of accounting record-keeping and auditing with account of the regulatory requirements. 
We have the possibility of online demonstration of information bases, application of electronic resources and licensed versions of the accounting process automation.

To attract the students' attention to the disciplines of the basic level of the professional cycle of the federal education standard of higher professional education of specialists in economics, specially-named classrooms with illustrated topical study guides were formed jointly with representatives of regional branch enterprises.

Another important aspect in the formation of general cultural and professional competencies is the material and technical support of the education process. For example, in the Kemerovo Institute (affiliated branch) of the "Plekhanov Russian University of Economics", speciallynamed classrooms are equipped with a complete hardware set to arrange and hold online educational events, such as webinars, online-conferences, etc.

For the purpose of acquisition of skills of professional assumption upon evaluation of the facts importance (significance) and cost measurement of the economic life for the purposes of accounting, reporting and auditing, our department has established affiliated branches at the premises of the Territorial Body of the Federal State Statistics Service in the Kemerovo Region and leading specialized enterprises in the Kemerovo Region.

At the stage of specialist retraining in the area of accounting, analysis and auditing, "Adult Professional Education Center" has been established and operates successfully at the premises of the higher education institution. It allows to observe consistency of the educational process of professional accountants training.

Within the limits of advanced training $(20-250$ hours), we implement programs focused on the update of theoretical and practical knowledge, specialist skill improvement that is necessary due to constantly rising requirements to their qualification. The offered programs are attractive both for students and for all specialists aiming to acquire new knowledge and professional skills required for career building.

However, in our opinion, in order to make the whole accounting and reporting system fully compliant with modern requirements and contribute to the development of the profession as such, the following measures are necessary:

- At the school education level, it is necessary to arrange events for orienting future applicants to higher education institutions and encouraging them to choose a certain profession. We believe that not only specialized educational institutions must take part in this process within the framework of their career guidance work, but also self-regulatory organizations of accountants and auditors via their regional offices;

- In our opinion, at the level of secondary or higher professional education, bachelor's and master's programs, it is necessary to implement a system of the so-called "double diploma" more actively, which would provide the opportunity of education at foreign educational institutions of certain specialization. Such programs surely exist, but they are hardly available for regions. We believe that this task must be solved at the government level, in case the state is interested in having highly-qualified specialists;

- At the level of economic entities, it is required to deal not only with further advanced training of specialists in the area of accounting, but also to involve them in the discussion of training programs themselves with account of their practical specialization.

Thus, in our opinion, the system of professional accountants training must have strong state support with carefully developed and structured training programs at all stages-from school days until specialization practicing. Only in that case, the accountant's activity in new economic circumstances will meet the demand of economic entities for diagnostics and generation of measures aimed at preservation of their economic well-being throughout the life and will contribute to performance of fundamentally new types of work ensuring an economy growth and attraction of necessary investments to its real sector.

All these actions performed together will not only contribute to the accounting system development, but also allow to bring the accountant profession to a whole new level, meeting modern economic circumstances, and will result in the achievement of absolute compliance of the current model of Russian professional education with the changing demands of the society and long-term tasks of the society and economy development as a whole.

\section{Conclusion}

Having examined the issues of compliance of the current model of Russian professional education with the changing demands of the society and long-term tasks of the society and economy development as a whole, we have come to a conclusion that at the current development stage, the requirements to an economist in the area of accounting, analysis and auditing have been raised significantly, which has caused the necessity of implementation of 
comprehensive education programs that are currently practiced by means of implementation of a multilevel system of specialist training in this field.

In the result of the conducted research, the authors have proposed a set of measures on the studied topic for further discussion about the modern prospects of higher professional education development in Russia.

\section{References}

1. Federal national educational standard of higher professional education for the training discipline 080100 Economic (bachelor qualification (degree) approved by the Order of the Ministry of Education and Science of Russia dated 21.12.2009 \#747 [in Russian].

2. Accounting Regulation. GARANT system. Available from: http://base.garant.

3. AR 22/2010 Correction of Mistakes in the Accounting Records and Reports. Available from: http://sprbuh.systecs. $\mathrm{ru} / \mathrm{uchet} / \mathrm{pbu} / \mathrm{pbu}$ _22_2010.html [in Russian].

4. AR 23/2011 Cash Flow Statement. Available from: http:// sprbuh.systecs.ru/uchet/pbu/pbu_23_2011.html [in Russian].

5. AR 24/2011 Accounting of Expenses for Natural Resources Development. Available from: http://sprbuh.systecs. ru/uchet/pbu/pbu_24_2011.html [in Russian].3036/3/\#block_130\#ixzz3nCgFN Kd2B2\%D0\%B0\% D 0 \% B D\%D0\%B8\%D1\%8F_2013-2020.pdf [in Russian].

6. AR 1/2008 Accounting Policy of an Organization. Available from: http://sprbuh.systecs.ru/uchet/pbu/pbu_1.html [in Russian].

7. AR 2/2008 Construction Contracts Accounting. Available from: http://sprbuh.systecs.ru/uchet/pbu/pbu_2.html [in Russian].

8. AR 3/2006 Accounting of Assets and Liabilities in Foreign Currency. Available from: http://sprbuh.systecs.ru/uchet/ $\mathrm{pbu} / \mathrm{pbu}$ _3.html [in Russian].

9. AR 4/99 Accounting Reports of an Organization. Available from: http://sprbuh.systecs.ru/uchet/pbu/pbu_4.html [in Russian].

10. AR 5/01 Inventory Accounting. Available from: http://sprbuh.systecs.ru/uchet/pbu/pbu_5.html [in Russian].

11. AR 6/01 Fixed Assets Accounting. Available from: http// sprbuh.systecs.ru/uchet/pbu/pbu_6.html [in Russian].

12. AR 7/98 Post-Reporting Events. Available from: http:// sprbuh.systecs.ru/uchet/pbu/pbu_7.html [in Russian].

13. AR 8/2010 Estimated Liabilities, Provisional Liabilities and Assets. Available from: http://sprbuh.systecs.ru/uchet/ pbu/pbu_8_2010.html [in Russian].

14. AR 9/99 Incomes of an Organization. Available from: http://sprbuh.systecs.ru/uchet/pbu/pbu_9.html [in Russian].

15. AR 10/99 Expenses of an Organization. Available from: http://sprbuh.systecs.ru/uchet/pbu/pbu_10.html [in Russian].

16. AR 11/2008 Related Parties Disclosure. Available from: http://sprbuh.systecs.ru/uchet/pbu/pbu_11.html [in Russian].

17. AR 12/2010 Segmented Information. Available from: http://sprbuh.systecs.ru/uchet/pbu/pbu_12_2010.html [in Russian].

18. AR 13/2000 Government Assistance Accounting. Available from: http://sprbuh.systecs.ru/uchet/pbu/pbu_13.html [in Russian].

19. AR 14/2007 Intangible Assets Accounting. Available from: http://sprbuh.systecs.ru/uchet/pbu/pbu_14.html [in Russian].

20. AR 15/2008 Accounting of Expenses for Loans and Credits. Available from: http://sprbuh.systecs.ru/uchet/pbu/ pbu_15.html [in Russian].

21. AR 16/02 Terminated Activity Disclosure. Available from: http://sprbuh.systecs.ru/uchet/pbu/pbu_16.html [in Russian].

22. AR 17/02 Accounting of Expenses for R\&D and Technological Works. Available from: http://sprbuh.systecs.ru/uchet/ pbu/pbu_17.html [in Russian].

23. AR 18/02 Profit Tax Accounting of Organizations. Available from: http://sprbuh.systecs.ru/uchet/pbu/pbu_18.html [in Russian].

24. AR 19/02 Investments Accounting. Available from: http:// sprbuh.systecs.ru/uchet/pbu/pbu_19.html [in Russian].

25. AR 20/03 Joint Venture Information Disclosure. Available from: http://sprbuh.systecs.ru/uchet/pbu/pbu_20.html [in Russian].

26. AR 21/2008 Change of Estimated Values. Available from: http://sprbuh.systecs.ru/uchet/pbu/pbu_21.html [in Russian]. 